\title{
YIELD AND PHYSIOLOGICAL INDICES OF LENTIL GENOTYPES AGAINST DROUGHT STRESS
}

\author{
B. Ahmed ${ }^{1}$, A.S. Mitu ${ }^{2}$, M. Sultana ${ }^{3}$, N. Tasnim ${ }^{4}$ and A.H.M.M.R. Talukder ${ }^{5}$ \\ ${ }^{135}$ Bangladesh Agricultural Research Institute, Gazipur-1701 \\ ${ }^{2}$ Bangladesh Suger Crop Research Institute, Pabna-6620 \\ ${ }^{4}$ Sher-e- Bangla Agricultural University, Dhaka-1207 \\ Corresponding E-mail: bulbul@bari.gov.bd
}

(Received: 13 October, 2020, Accepted: 01 November, 2020)

Keywords: Ascorbate peroxidase (APX), Catalase (CAT), Peroxide dismutase (POD), Malondialdihyde (MDA) Physiological indices, Drought, Lentil

\begin{abstract}
Four lentil genotypes/varieties BLX-010014-9, ILI-5143, BARI Mosur-3 and BARI Mosur-2 were given irrigation regimes (with and without irrigation) to evaluate the physiological indices of genotypes against drought stress. The experiment was conducted during rabi (winter) season of 2017-18 under pot culture at the Plant Physiology Division of Bangladesh Agricultural Research Institute (BARI). The experimental design was randomized completed block (RCBD) with six replications. Irrespective of genotypes/varieties, physiological parameters as well as seed yield were greatly affected due to irrigation regimes. Based on physiological parameters like accumulation of chlorophyll, enzymatic and non-enzymatic antioxidantthe genotype BLX-010014-9 was found to be drought tolerant due to its higher and lower values of enzymatic and nonenzymatic antioxidant indices (greater CAT, POD, APX and lower MDA) across the irrigation levels treatment. This genotype may be further explored to characterize its genes and mechanisms against drought stress for increased lentil production and way to developing the drought tolerant variety/varieties.
\end{abstract}

\section{Introduction}

Among the various abiotic stresses, drought is a great crop yield limiting phenomenon in many areas of the world (Rahimi, 2016). Directly or indirectly, drought affects at morphological, physiological, biochemical and molecular levels of crops (Saeedipour, 2012) that adversely reduce the plant growth and productivity (Wang et al., 2001). Estimated yield reduction for cereal crops like maize and wheat were up to $21 \%$ and $40 \%$, respectively due to severe drought as reported by Daryanto et al. (2016). Legume crop like lentil is also vulnerable to drought stress at reproductive growth stage that limits its yield (Farooq et al., 2016) by 6 to 54\% (Oweis et al., 2004). Acclimation of plants to drought stress is the result of adaptive changes in plant growth and physiological processes. It is well known that abiotic stresses can cause oxidative damage to plants, either directly or indirectly through the formation of reactive oxygen species (ROS) while plants survive with the increasing production of antioxidant enzyme like ascorbate peroxidase (APX, EC.1.11.1.11), catalase (CAT, EC 1.11.1.6) and peroxide dismutase (POD, EC 1.15.1.1) which can scavenge ROS as a physiological mechanism of drought tolerance (Das and Choudhary, 2016). So, this mechanism can play a vital role for breeder to identify lentil genotypes, keep on high level yield production under drought conditions. Earlier Ahmed et al. (2016) observed the genotype BLX-010014-9 as most drought tolerant giving comparative relative yield where physiological mechanism is needed to be explored. Hence, this experiment was conducted to explore the changes in physiological responses against drought tolerance indices of lentil. 


\section{Materials and Methods}

An experiment was conducted in pot house of Plant Physiology Division of BARI to evaluate the yield differences and physiological mechanism of lentil genotypes against drought tolerance indices. The experiment was conducted during November, 2017 to February, 2018. Earlier selected four lentil genotypes/varieties, BLX-010014-9, ILI-5143, BARI Moshur-3, and BARI Moshur-2 based on their relative yield performance under drought conditions were used in this experiment under. The test crops were grown under irrigation (control) and drought (no irrigation) conditions. The control plants were maintained with proper irrigation started at 30 days after sowing (DAS) while the other set of plants were subjected to water stress by withholding irrigation during whole growing period. The study was laid out in Randomized Complete Block Design with six replications and each pot was considered as one replication. To carry out the experiment total $48(26 \mathrm{~cm}$ top diameter, $20 \mathrm{~cm}$ base diameter and 25 $\mathrm{cm}$ in height) pots were arranged with placement of 24 pots in two replicate blocks in the pot house. Soil and well decomposed farm yard manure were mixed properly in 4:1 volume ratio and kept in each pot containing $12 \mathrm{~kg}$ of soil. Fertilizers @ 12-16-20-12-1.0-0.5 kg ha ${ }^{-1}$ of N-P- K-S-Zn-B were applied in the form of urea, triple super phosphate, muriate of potash, sulphur and zinc sulphate and boron, respectively (FRG, 2012). Each pot received double rate of 0.16-0.48-0.24-0.42-0.16-0.018 g urea, triple super phosphate, muriate of potash, sulphur and zinc sulphate and boron, respectively. Provax200 WP treated seeds were sown on 27 November, 2017. Seven to ten healthy and uniform size seeds were sown each pot as per variety arrangement. Subsequently, five healthy seedlings in each pot were maintained. Crop growth and physiological parameters were recorded with time. To measure the physiological parameters sampling was done on sunny days within the period of 11.00 am to $1.30 \mathrm{pm}$ when drought stress symptoms were visible in crops.

\section{Physiological parameter}

\section{Chlorophyll accumulation of leaves $\left(\mathrm{mg} \mathrm{g}^{-1} \mathrm{FW}\right)$}

Second or third leaf sample from plant of each plot was collected and weighed out in $0.5 \mathrm{~g}$ (fresh weight). Then the sample was treated using $10 \mathrm{ml}(\mathrm{V})$ of $80 \%$ acetone approximately 48 hours until the leaf turned white under dark condition. The optical density was measured with UV-1800 spectrophotometer (Shimadzu, Japan) against $80 \%$ acetone as blank at $663 \mathrm{~nm}$ (OD663) and at $645 \mathrm{~nm}$ (OD645) for chlorophyll a ( $\mathrm{Chl}$ a) and chlorophyll b (Chl b), respectively. The chlorophyll concentrations (Chl) were determined using following formula as described by Arnon (1994).

Chl a $\left(\mathrm{mg} \mathrm{g}^{-1}\right)=[12.7($ OD 663)-2.69(OD645) $] \times \mathrm{v} /(1000 \times \mathrm{W})$

$\mathrm{Chl} \mathrm{b}\left(\mathrm{mg} \mathrm{g}^{-1}\right)=[22.9(\mathrm{OD} 645)-4.68(\mathrm{OD} 663)] \times \mathrm{v} /(1000 \times \mathrm{W})$

Total Chlorophyll $\left(\mathrm{mg} \mathrm{g}^{-1}\right)=[20.2($ OD 645$)+8.02($ OD 663) $) \times \mathrm{V} /(1000 \times \mathrm{W})$

\section{Bio-chemical analysis}

\section{Enzyme extraction and Assays}

To perform bio-chemical analysis fully expanded $3^{\text {rd }}$ leaf from the top of plant of each plot was collected and kept in laboratory within zipper bag keeping in ice box. Using a pre-cooled mortar and pestle, $0.5 \mathrm{~g}$ of leaf tissue was homogenized in $8 \mathrm{ml}$ of $50 \mathrm{mM}$ ice-cold Tris-HCl buffer buffer ( $\mathrm{pH} 7.2)$ containing $1 \mathrm{mM} \mathrm{Na} 2 \mathrm{HPO} .12 \mathrm{H}_{2} \mathrm{O}$ and $1 \mathrm{mM} \mathrm{NaH} \mathrm{NO}_{2} \mathrm{PO} 2 \mathrm{H}_{2} \mathrm{O}$. The homogenates were centrifuged at $10,000 \times \mathrm{g}$ for 20 minute. Supernatants were collected after centrifugation and used to determine biochemical compounds such as CAT, POD and MDA. The collected supernatant was stored at $4{ }^{\circ} \mathrm{C}$ temperature until use. All biochemical activities were performed by SHIMADZU UV spectrophotometer (UV-1800).

Catalase (CAT, EC: 1:11:1.6): Catalase activity was carried out in a 3-ml reaction volume containing $2.8 \mathrm{ml}$ of $50 \mathrm{mM}$ Tris- $\mathrm{HCl}$ buffer (pH 7.2, not containing EDTA), $100 \mu 1$ of enzyme extract and $100 \mu 1$ of $300 \mathrm{mM} \mathrm{H} 2 \mathrm{O} 2$ from $30 \% \mathrm{H}_{2} \mathrm{O}_{2}$ was taken in a quevette which was placed in measuring chamber of 
UV spectrophotometer. Activity was determined at $240 \mathrm{~nm}$ wavelength, which measures the decrease in absorbance for 30 second. The activity was calculated using the extinction coefficient of $39.4 \mathrm{mM}$ $\mathrm{cm}^{-1}$ according to $\mathrm{Wu}$ et al. (2003).

Peroxidase (POD, EC 1.11.1.7): POD activity was carried out in a 3-ml reaction volume containing $2.7 \mathrm{ml}$ of $50 \mathrm{mM}$ Tris-HCl buffer (pH 7.2, not containing EDTA), $100 \mu 1$ of enzyme extract and $100 \mu \mathrm{l}$ of $1.5 \%$ Guaicol, $100 \mu \mathrm{l}$ of $300 \mathrm{mM} \mathrm{H} 2 \mathrm{O} 2$ from $30 \% \mathrm{H}_{2} \mathrm{O}_{2}$ was taken in a quevette which was kept in measuring chamber of UV spectrophotometer. Activity was determined at $240 \mathrm{~nm}$ wavelength, which measures the decrease in absorbance for $1 \mathrm{~min}$. The activity was calculated using the extinction coefficient of $39.4 \mathrm{mM} \mathrm{cm}^{-1}$ according to Wu et al. (2003).

\section{MDA (Lipid peroxidation) assays:}

Malondialdihyde (MDA) (lipid peroxidation) was measured as per protocol of Wu et al. (2003). $1.5 \mathrm{ml}$ plant enzyme extract and $2.5 \mathrm{ml}$ reaction solution (5\% Trichloroacetic acid $+0.6 \%$ thiobarbituric acid) was mixed together in a small tube and gave in hot water bath at $95{ }^{\circ} \mathrm{C}$ for 15 minutes and then gave immediately in ice bath. Subsequently, the reaction solution was centrifuged @ $4800 \mathrm{rpm}$ for 10 minutes. The absorbance of the supernatant was recorded at $532 \mathrm{~nm}$. Correction of non-specific turbidity was made by subtracting the absorbance value read at $600 \mathrm{~nm}$. The level of lipid peroxidation was expressed as nmol g ${ }^{-1}$ fresh weight, with a molar extinction coefficient of $0.155 \mathrm{mMcm}^{-1}$.

Ascorbate peroxidase (APX, EC: 1.11.1.11) activity was assayed following the method of Chen et al. (2010). The reaction buffer solution contained $50 \mathrm{mM} \mathrm{K-phosphate} \mathrm{buffer} \mathrm{(pH} \mathrm{7.0),} 0.5$ mMASC, 0.1 $\mathrm{mM} \mathrm{H} \mathrm{O}_{2}, 0.1 \mathrm{mM}$ EDTA, and enzyme extract in a final volume of $0.7 \mathrm{ml}$. The reaction was started by the addition of $\mathrm{H}_{2} \mathrm{O}_{2}$, and the activity was measured by observing the decrease in absorbance at $290 \mathrm{~nm}$ for 1 min using an extinction coefficient of $2.8 \mathrm{mM}^{-1} \mathrm{~cm}^{-1}$.

\section{Agronomic Parameters}

At maturity stage three plants from each treatment combination were collected and agronomic parameters like plant height, pods plant ${ }^{-1}$, seeds $\operatorname{pod}^{-1}, 100$-seed weight and seed yield plant ${ }^{-1}$ was recorded.

The recorded data were statistically following MSTAT-C. The treatment means were compared by Least Significant Difference (LSD) test at 5\% level of significance (Gomez and Gomez, 1984).

\section{Results and Discussion}

\section{Synthesis of antioxidant enzyme under drought condition}

Stress generally induces accumulation of free radicals or ROS and causes oxidative fracture in plant cells. The synthesized antioxidant enzyme by stressed cultivars/varieties scavenges the ROS. Overall, activity in synthesis of antioxidant enzyme like POD, CAT, APX, and MDA by different lentil genotypes under drought stressed compared with the unstressed is given below.

Drought tolerance or sensitivity of a genotype/variety is positively related with synthesize of antioxidant enzyme (Chutipaijit, 2016). Water stress significantly increased POD activity in all cultivars except the genotype ILI-5143. BARI Mosur-2 and BLX-010014-9 synthesized 15.73\% and $12.95 \%$ higher POD under drought condition comparing with control. The genotype ILI-5143 synthesized $86.0 \%$ lower POD which indicates the drought sensitivity of it (Figure 1A). The measured activities of an antioxidant enzyme like ascorbate peroxidase (APX) were synthesized significantly higher in genotype/cultivar BLX-010014-9 and BARI Mosur-3 under drought and control (irrigated) conditions. The genotype/variety BLX-010014-9, ILI-5143 and BARI Mosur-2 synthesized 327.4\%, $336.9 \%$ and $95.4 \%$ higher APX under drought environment over control (Figure 1B). 

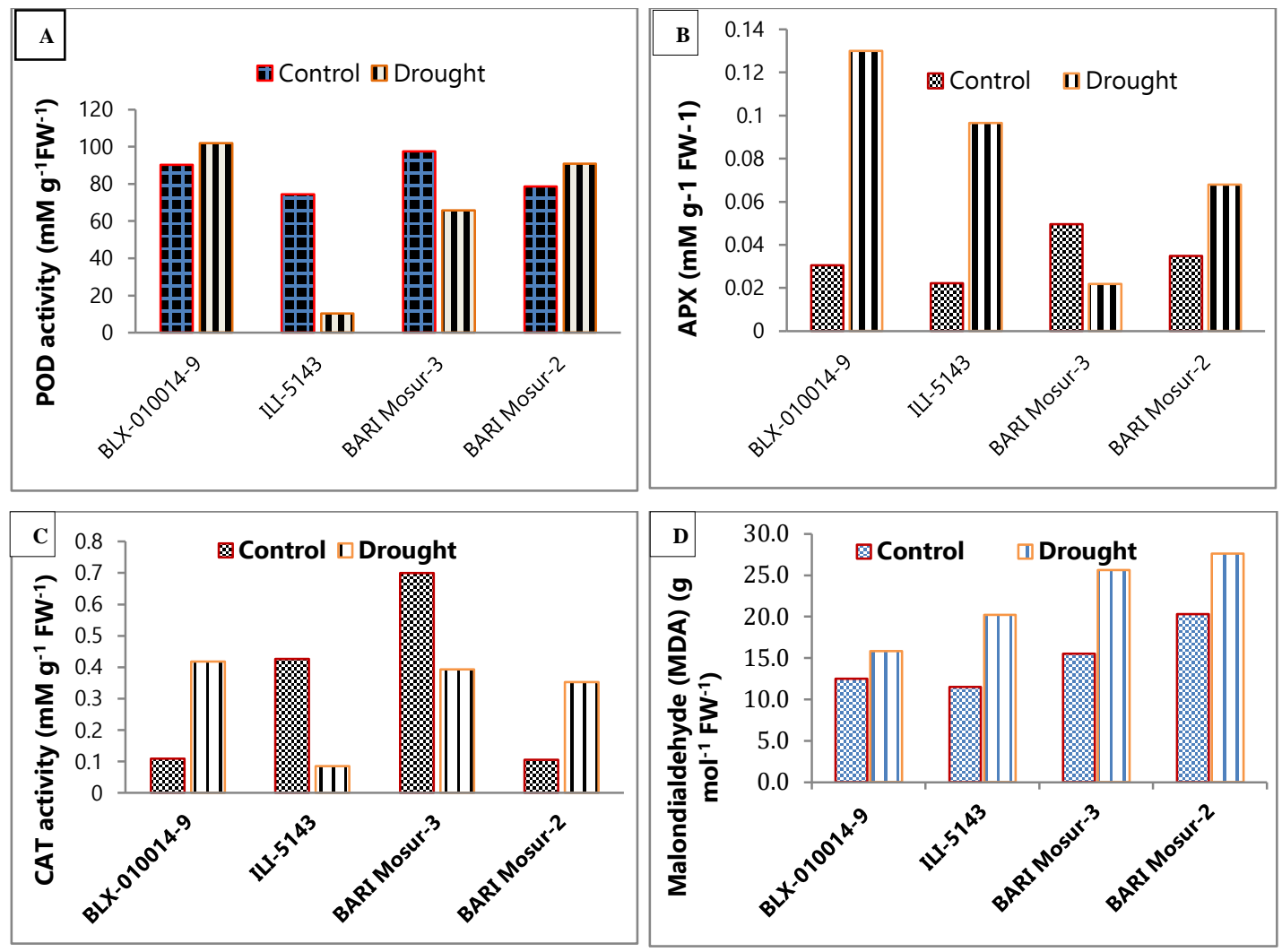

Fig. 1. Effect of drought stress on enzymatic antioxidant (A) Peroxide dismutase (POD), Ascorbate peroxidase (APX), (C) Catalase (CAT) and non-enzymatic antioxidant Malondialdihyde (MDA) activities in lentil genotypes/varieties comparing with control

Catalase activity (CAT) was measured in four lentil varieties/cultivars when wilting symptom was sharply appeared under drought condition (Figure 1C). Compared with the control, there was significantly higher CAT activity upon exposure to drought stress in genotype/cultivar BLX010014-9 and BARI Mosur-2. The accumulation of higher level CAT enhanced scavenging ability for $\mathrm{H}_{2} \mathrm{O}_{2}$ in cultivar BLX-010014-9 and BARI Mosur-2 inhibited the accumulation of ROS and thus protected the plants from lipid peroxidation of membrane systems and oxidative damages under drought stress. Cell membrane damage was monitored by MDA (malondialdehyde) content of the leaf and which showed maximum values in all the studied lentil varieties/genotypes subsequent to water stress condition thus reflects the lower extent of tolerance to drought. Hameed et al. (2011) reported that higher drought tolerance cultivar shows lower MDA value when subjected to stress. All species exhibited a significant rise in their MDA content subsequent to drought stress except for genotype BLX-010014-9. At this point, the increase was much higher in BARI Mosur-3 and ILI-5143 which was $75.6 \%$ and $65.1 \%$, respectively over control. The lowest MDA value was found in genotype BLX010014-9 which was $26.7 \%$ over control (Figure 1D). Consequently the higher values of antioxidant enzymes and lower value of MDA suggested the genotype BLX-010014-9 as drought tolerant which can prevent the cell membrane damages effectively under drought stress.

\section{Effect of drought stress on accumulation of photosynthetic pigment}

All genotypes significantly reduced the accumulation of chlorophyll pigment like chlorophyll a, chlorophyll $\mathrm{b}$ and total chlorophyll when subjected to drought stress. Under restricted water supply 
condition the variety BARI Mosur-3 significantly reduced the $(55.1 \%)$ chlorophyll a pigment over control. But, all cultivars/varieties showed the significant inverse relations under drought for the accumulation of chlorophyll $\mathrm{b}$ pigment. Chl b content decrease was evaluated till $25 \%$ in genotype BLX-010014-9 and 53\% in variety BARI Mosur-3. Total chlorophyll content decreased in BLX010014-9 by (33.9\%), ILI-5143 (34\%) and BARI Mosur-3 (51.0\%), and increased in BARI Mosur-2 $(2.60 \%)$. The reduction of total chlorophyll $(\mathrm{Chl}, \mathrm{a}+\mathrm{b})$ under drought stress indicates the inferior capacity for light harvesting by genotypes. Similarly, the result of the study agreement with the study of Mafakheri et al. (2010) who described that drought stress significantly decreased chlorophyll a, chlorophyll $\mathrm{b}$ and total chlorophyll content Chickpea cultivars.



Fig. 2. Accumulation of $\mathrm{Chl} \mathrm{a}, \mathrm{Chl} b$ and total Chlorophyll $(\mathrm{a}+\mathrm{b})$ of different lentil genotypes/varieties under drought condition

\section{Morphological growth, yield contributing and yield parameters of Lentil}

Irrespective of lentil varieties the plant height was reduced $10.86 \%$ under drought condition over control (Table 1). Genotype ILI-5143 showed the tallest plant $(38.62 \mathrm{~cm})$ and followed by the genotype BLX-010014-9 $(33.65 \mathrm{~cm})$ along with irrigation. Even both cultivars had better performance under drought conditions $(33.29,31.27 \mathrm{~cm}$, respectively) over others. BARI Mosur-2 showed shorter plants $(25.85 \mathrm{~cm})$ with drought treatment even it was poor $(30.25 \mathrm{~cm})$ in irrigated condition compare to others indeed (Table 1). The declination of plant height in drought stress can be owing to the relative reduction of augmentation and water loss of the protoplasm (Nonami, 1998) which causes to the reduction of turgor pressure and cell division (Taiz and Zeiger, 2006). Yield supporting components act as a noble indicators under drought stress and our study showed the significant reduction in number of pods plant ${ }^{-1}, 100$-seed weight and yield under drought stress condition. Similarly, Asfaw and Blair (2014) also reported that yield and yield supporting components were reduced significantly in common beans under drought stress. Irrespective of genotypes/varieties the highest number of pods plant ${ }^{-1}$ were found when they were grown under irrigated condition which was $24.7 \%$ higher over drought condition. The genotype BLX-010014-9 showed the highest pods plant ${ }^{-1}$ (45.63) followed by the genotype ILI-5143 (42.13) irrespective of irrigation treatments. Combined effect showed that the genotype BLX-010014-9 under control condition produced the highest pods plant ${ }^{-1}$ (45.63) while the variety BARI Mosur-3 under drought condition produced the lowest pods plant ${ }^{-1}(22.34)$ (Table 1). The number of pods in plant $^{-1}$ were reduced under drought stressed over the irrigated condition might be due to reduction in flower fertilization and aggregate of flower shattering. The maximum 100 -seed weight was recorded in genotype BLX-010014-9 and ILI-5143 (22.73 g and $22.38 \mathrm{~g}$, respectively) under irrigated conditions and the lowest was in ILI-5143, BARI Mosur-3 and BARI Mosur-2 (20.31, 
20.11, $20.10 \mathrm{~g}$, respectively) under without irrigation condition (Table 1). Irrespective of varietal difference seed yield plant ${ }^{-1}$ was reduced $39.0 \%$ under drought condition might be due to the reduction in number of pods plant $^{-1}$. This finding is corroborated with the results of Pilbeam et al. (1992) who opined that grain yield of legume decreases greatly under drought condition due to the reduction of pods plant ${ }^{-1}$. Combined effect showed that BLX-010014-9 under watery condition produced the highest seed yield $\left(2.65 \mathrm{~g} \mathrm{plant}^{-1}\right)$ which was attributed by the maximum number of pods in plant $^{-1}$. The grain yield was decreased 29.0\%, 29.8\%, 49.0\% and 52.0\% for genotypes BLX-010014-9, ILI-5143, BARI Mosur-3 and BARI Mosur-2, respectively when those were given no irrigation.

Table 1. Combined effect of irrigation regimes and genotypes on growth, yield and yield attributes of lentil during rabi 2017-2018

\begin{tabular}{|c|c|c|c|c|c|c|}
\hline $\begin{array}{c}\text { Irrigation } \\
\text { regimes }\end{array}$ & Genotype/Variety & $\begin{array}{c}\text { Plant } \\
\text { height } \\
(\mathbf{c m})\end{array}$ & $\begin{array}{c}\text { Pods } \\
\text { plant }^{-1} \\
(\text { No. })\end{array}$ & $\begin{array}{l}\text { Seeds pod }^{-1} \\
\text { (No.) }\end{array}$ & $\begin{array}{c}\text { 100-seed } \\
\text { weight }(\mathrm{g})\end{array}$ & $\begin{array}{c}\text { Yield } \\
\text { plant }^{-1} \\
(\mathrm{~g})\end{array}$ \\
\hline \multirow{4}{*}{$\begin{array}{l}\text { Control (with } \\
\text { irrigation) }\end{array}$} & BLX-010014-9 & 33.65 & 45.63 & 1.96 & 22.73 & 2.65 \\
\hline & ILI-5143 & 38.62 & 42.13 & 1.56 & 22.38 & 2.52 \\
\hline & BARI Mosur-3 & 31.20 & 26.39 & 1.52 & 21.35 & 2.21 \\
\hline & BARI Mosur-2 & 30.25 & 35.26 & 1.31 & 21.31 & 2.13 \\
\hline \multirow{4}{*}{$\begin{array}{l}\text { Drought (no } \\
\text { irrigation) }\end{array}$} & BLX-010014-9 & 31.27 & 36.32 & 1.63 & 21.56 & 1.86 \\
\hline & ILI-5143 & 33.29 & 35.81 & 1.50 & 20.31 & 1.79 \\
\hline & BARI Mosur-3 & 28.63 & 22.34 & 1.12 & 20.11 & 1.12 \\
\hline & BARI Mosur-2 & 25.85 & 25.34 & 1.15 & 20.10 & 1.02 \\
\hline $\mathrm{CV}(\%)$ & & 5.43 & 9.63 & 0.34 & 4.21 & 7.52 \\
\hline $\operatorname{LSD}_{(0.05)}$ & & 11.3 & 22.3 & NS & 1.23 & 1.36 \\
\hline
\end{tabular}

\section{Conclusion}

The results showed that large genetic variations were evident as drought tolerant trait. Genotype BLX010014-9 was found comparatively tolerant to drought stress as compared to others by showing the pertinent physiological indices like greater CAT, POD, APX and lower MDA. So, BLX-010014-9 would be a potential genotype for cultivating in the drought prone areas and also be used for development of the drought tolerant variety/varieties of lentil.

\section{References}

Ahmed, B., M.J. Alam, M.A. Hossain, M. Sultana, M.N. Islam and M.R. Ali. 2016. Study of selected Lentil genotypes against drought. Intl. J. Appl. Sci. 2(2): 95-99.

Arnon, D.I. 1994. Copper enzymes in isolated chloroplasts. Polyphenol oxidase in Beta vulgaris. Plant Physiol. 24: 1-15.

Asfaw, A and M.W. Blair. 2014. Quantification of drought tolerance in Ethiopian common Bean varieties. Agric. Sci. 5: 124-139

Chen, F., F. Wang, F.B. Wu, W.H. Mao and G.P. Zhang. 2010. Modulation of exogenous glutathione in antioxidant defense system against $\mathrm{Cd}$ stress in the two barley genotypes differing in Cd tolerance. Plant Physiol. Biochem. 48: 663-672. doi:10.1016/ j.plaphy.2010.05.001. PubMed: 20605723.

Chutipaijit, S., S. Cha-um and K. Sompornpailin. 2016. High contents of proline and anthocyanin increase protective response to salinity in Oryza sativa L. spp. indica. Aust. J. Crop Sci. 5: 1191-1198 
Daryanto, S., L. Wang and P.A. Jacinthe. 2016. Global synthesis of drought effects on maize and wheat production. PLoS ONE 11:e0156362 10.1371/ journal.pone. 0156362.

Das, K. and A.R. Choudhury. 2016. Reactive oxygen species (ROS) and response of antioxidants as ROSscavengers during environmental stress in plants. Redox Homeostasis Managers in Plants under Environmental Stresses, p.53.

Farooq M., N. Gogoi, S. Barthakur, B. Baroowa, N. Bharadwaj and S.S. Alghamdi. 2016. Drought stress in grain legumes during reproduction and grain filling. J. Agron. Crop Sci. 203: 81-102. doi: 10.1111/jac.12169.

FRG. 2012. Fertilizer Recommendation Guide, Bangladesh Agricultural Research Council (BARC), Farmgate, Dhaka 1215. 274p.

Gomez, A.A. and A.A. Gomez. 1984. Statistical procedure of Agricultural Research. Second Edition. John Wiley and Sons. New York.

Hameed, A., N. Bibi, J. Akhter and N. Iqbal. 2011. Differential changes in antioxidants, proteases, and lipid peroxidation in flag leaves of wheat genotypes under different levels of water deficit conditions. Plant Physiol. Biochem. 49: 178-185. doi:https://doi.org/10.1016/ j.plaphy.2010.11.009. PubMed: 21159517.

Mafakheri, A., A. Siosemardeh, B. Bahramnejad, P.C. Struik and E. Sohrabi. 2010. Effect of drought stress on yield, proline and chlorophyll contents in three chickpea cultivars. Aust. J. Crop Sci. 4(8): 580585.

Nonami, H. 1998. Plant water relations and control of cell elongation at low water potentials. J. Plant Res. 111: 373-382. doi: 10.1007/BF02507801.

Oweis, T., A. Hachum and M. Pala. 2004. Lentil production under supplemental irrigation in a Mediterranean environment. Agric. Water Manag. 68(3): 251-265.

Pilbeam C.J., J.K. Akatse, P.D. Hebblethwaite and C.D. Wright. 1992. Yield production in two contrasting forms of spring-sown faba beans in relation to water supply. Field Crops Res. 29: 73-287.

Rahimi, M.H., S. Houshmand, M. Khodambashi, B. Shiran and S. Mohammady. 2016. Effect of drought stress on Agro-morphological traits of lentil (Lens culinaris Medik.) recombinant inbred lines. Bangladesh J. Agril. Res. 41(2): 207-219.

Saeedipour, S. 2012. Effect of post-anthesis water deficit on yield and some physiological parameters on two wheat cultivars. Afr. J. Agric. Res. 7: 3446-3452.

Taiz, L. and E. Zeiger. 2006. Plant Physiology, 4th Edn. Sunderland, MA: Sinauer Associates Inc Publishers.

Wang, W.X., B. Vinocur, O. Shoseyov and A. Altman. 2001. Biotechnology of plant osmotic stress tolerance: physiological and molecular considerations. Acta Hortic. 560: 285-292. doi: 10.17660/ActaHortic.2001.560.54.

Wu, F.B., G.P. Zhang and P. Dominy. 2003. Four barley genotypes respond differently to cadmium lipid peroxidation and activities of antioxidant capacity. Environ. Exp. Bot. 50: 67-78. doi:10.1016/S0098-8472(02)00113-2. 